\title{
ANALISIS PENGARUH KOMPETENSI KERJA DAN BEBAN KERJA TERHADAP PRODUKTIVITAS KERJA SURVEYOR PADA KEGIATAN CONTAINER SURVEY DI DEPO BIMARUNA JAYA
}

\section{ANALYSIS OF THE EFFECT OF WORK COMPETENCE AND WORKLOAD ON SURVEYOR'S WORK PRODUCTIVITY IN CONTAINER SURVEY ACTIVITIES}

\author{
Winoto Hadi a, ${ }^{*}$, Kencana Verawati a,2 Rani Ismorilda Handayani a,3 \\ a Transportasi, Teknik Sipil, Universitas Negeri Jakarta, Jl.Rawamangun Muka, Jakarta Timur, Indonesia. \\ 1*winoto unj@yahoo.com. ${ }^{2}$ kencanaverawati@unj.ac.id. ${ }^{3}$ raniismorilda99@gmail.com
}

\section{ABSTRACT}

Bimaruna Jaya Depot is one of the companies engaged in services related to the handling and stacking of containers. This company is currently experiencing problems regarding employee work productivity which is decreasing from month to month from the achievement target. The purpose of this study was to determine whether work competence and workload affect the work productivity of surveyors in container survey activities at Bimaruna Jaya Depot. The research method used is direct observation to the field, distributing questionnaires to insurveyors and out, estimators, andsupervisors maintenance and repair and interviews with depot managers andsupervisors maintenance and repair. The type of research used is descriptive qualitative by distributing questionnaires and interviews, namely purposive sampling technique. The results of the study indicate that the work productivity of aofficer surveyor can be influenced by competence and workload with targets set by the company.

Keywords: Competence, Workload, Productivity, Depot, Surveyor.

\begin{abstract}
ABSTRAK
Depo Bimaruna Jaya merupakan salah satu perusahaan yang bergerak di bidang jasa pelayanan terkait dengan penanganan dan penumpukkan peti kemas. Perusahaan ini sedang sedang mengalami permasalahan mengenai produktivitas kerja karyawan yang dari bulan ke bulan terjadi penurunan dari target pencapaian. Tujuan penelitian ini adalah untuk mengetahui apakah kompetensi kerja dan beban kerja berpengaruh terhadap produktivitas kerja surveyor pada kegiatan container survey di Depo Bimaruna Jaya. Metode penelitian yang digunakan adalah pengamatan secara langsung ke lapangan, melakukan penyebaran kuesioner kepada petugas surveyor in dan out, estimator, dan supervisor maintenance and repair dan wawancara kepada manajer depo dan supervisor maintenance and repair. Jenis penelitian yang digunakan adalah deskriptif kualitatif dengan penyebaran kuesioner dan wawancara yaitu teknik purposive sampling. Hasil penelitian menunjukkan bahwa Produktivitas kerja seorang petugas surveyor dapat dipengaruhi oleh kompetensi dan beban kerja dengan target yang telah ditetapkan perusahaan.
\end{abstract}

Kata kunci : Kompetensi, Beban Kerja, Produktivitas, Depo, Surveyor. 


\section{A. Pendahuluan}

Pesatnya perkembangan teknologi transportasi saat ini menyebabkan banyaknya pilihan dalam memilih sistem moda transpotasi yang dapat digunakan untuk mendistribusikan suatu barang atau muatan. Menggunakan peti kemas sebagai sarana pembantu alat angkut muatan merupakan salah satu dari sistem tersebut. Pemilik peti kemas dalam penanganan peti kemas membutuhkan sebuah lahan yang luas untuk kegiatan pencucian, perawatan, perbaikan dan penyimpanan. Namun tidak semua pemilik peti kemas memiliki lahan yang luas oleh sebab itu, mucul sebuah perusahaan yang bergerak dibidang jasa yang dapat menangani dan merawat peti kemas atau biasa disebut depo peti kemas.

Depo peti kemas merupakan tempat didalam ataupun diluar daerah lingkungan kerja pelabuhan yang memiliki fungsi sebagai tempat penyimpanan, penumpukkan, pencucian, perawatan, perbaikan, bongkar dan muat peti kemas (Peraturan Menteri Perhubungan Nomor PM 83 Tahun 2016, 2016).

Penangangan peti kemas di depo-depo harus memiliki kualitas petugas yang berkompeten, hal ini dimaksudkan agar depo tersebut dapat bersaing dengan depo peti kemas lainnya. Kemampuan bekerja dalam diri seseorang yang dapat dilihat dari pengetahuan, keterampilan dan sikap kerja sesuai dengan standar yang telah ditetapkan disebut kompetensi (UndangUndang Republik Indonesia No. 13 Tahun 2003, 2003). Kompetensi juga dapat dimaksudkan sebagai kapasitas dari setiap individu dalam melakukan berbagai tugas dalam suatu pekerjaan (Hadi et al., 2021).

Produktivitas selalu dikaitkan dengan tingkat efektvitas dan efisiensi dimana efektivitas sebuah tingkatan keberhasilan dalam mencapai tujuan yang termasuk kepuasan dalam hasil yang dipenuhi dalam bentuk jasa atau barang. Sedangkan efisiensi sebuah rasio antara output sebenarnya dengan standar output yang diperoleh input selama proses produksi (Rahmayanti \& Tirtayadi, 2011).

Produktivitas kerja dapat menurun apabila dalam pembebanan pekerjaan berada pada tingkat yang lebih tinggi dari kemampuan, sebaliknya apabila tingkat pembebanan yang terlalu rendah dapat menyebabkan munculnya rasa bosan dan jenuh pada karyawan. Produktvitas kerja yang tinggi dapat mempengaruhi kesejahteraan para karyawannya (Hadi et al., 2021). Akibat yang timbul antara hubungan lingkungan kerja dengan tugastugas yang dilakukan sebagai keterampilan, serta persepsi dari pegawai dan tempat kerja disebut beban kerja (JUMANTORO et al., 2019). Sebuah 
permasalahan di dalam perusahaan tidak akan timbul apabila tenaga kerja bekerja sesuai dengan standar perusahaan. Namun, jika tenaga kerja bekerja dibawah standar perusahaan, maka beban kerja yang diterima akan melebihi kapasitasnya (Kurniawan et al., 2016).

Depo Bimaruna Jaya merupakan anak perusahaan dari Korindo Grup yang bergerak dalam bidang jasa penanganan dan penumpukkan peti kemas. Depo Bimaruna Jaya sedang mengalami permasalahan mengenai produktivitas kerja karyawan yang dari bulan ke bulan terjadi penurunan dari target pencapaian. Pada bulan Januari 2021 jumlah container yang disurvei sebanyak 7.321 TEUs dari tagetnya 7.395 TEUs, kemudian terjadi penurunan pada bulan Februari 2021 dari target 6.960 TEUs hanya menjadi 6.302 TEUs. Selanjutnya pada bulan Maret 2021 kembali terjadi penurunan dari target 9.570 TEUs hanya 9.242 TEUs yang diselesaikan. Lalu pada bulan April 2021 terjadi penurunan kembali dari target 9.135 TEUs menjadi 8.190 TEUs.

Penurunan jumlah container yang masuk dan keluar disebabkan oleh banyak faktor seperti kurang didukung oleh kompetensi karyawannya dan beban kerja seperti jam kerja yang melebihi standar pemerintah. Hal ini dapat mengakibatkan terjadinya lost survey yang disebabkan oleh kurangnya sumber daya manusia yang berkompeten ditandai dengan masih terdapat petugas survey yang belum memiliki sertifikat khusus keahlian dalam bidang survey dan kelelahan dalam bekerja dikarenakan jam kerja yang melebihi batas dari pemerintah yakni 12 jam untuk 1 shift.

Pada penelitian sebelumnya yang dilakukan oleh (JUMANTORO et al., 2019) menunjukkan bahwa motivasi kerja dan pelatihan mempengaruhi secara positif dan signifikan terhadap produktivitas kerja sedangkan kompetensi dan beban kerja mempengaruhi secara positif dan tidak signifikan terhadap produktivitas kerja sumber daya manusia.

Kegiatan container survey pada Depo Bimaruna Jaya merupakan faktor penting dalam keberhasilan usaha depo container. Menurut IICL (Institute of International Container Lessors) seorang surveyor container harus menguasai semua kodekode yang terdapat pada CEDEX (Container Equipment Data Exchange) yang meliputi kode komponen, lokasi kerusakan, jenis kerusakan, jenis perbaikan dan ketentuan-ketentuan kerusakan container yang telah diatur pada buku Guiden Inspection (Kennedy et al., 2018)

Tingkat ketelitian yang baik dan pengetahuan yang luas pada saat 
pemeriksaan container sangat diperlukan agar container tersebut dalam keadaan yang layak bila digunakan untuk kegiatan berikutnya. Dampak yang timbul jika petugas survey tidak teliti karena kelalahan dalam melakukan pemeriksaan terhadap container akan mengakibatkan risiko yang sangat fatal seperti kerugian materiil maupun non-materiil yang harus ditanggung oleh depo tersebut. Oleh karena itu kompetensi yang dimiliki oleh petugas surveyor dan beban kerja yang dibebankan sangat mempengaruhi produktivitas kerja.

Berdasarkan uraian di atas maka rumusan masalah dari penelitian ini yaitu "Pengaruh Kompetensi Kerja Dan Beban Kerja Terhadap Produktivitas Kerja Surveyor Pada Kegiatan Container Survey Di Depo Bimaruna Jaya”. Adapun tujuan dari penelitian ini adalah :

1. Untuk mengetahui kompetensi kerja berpengaruh terhadap produktivitas kerja surveyor pada kegiatan Container Survey di Depo Bimaruna Jaya.

2. Untuk mengetahui beban kerja berpengaruh terhadap produktivitas kerja surveyor pada kegiatan Container Survey di Depo Bimaruna Jaya.

3. Untuk mengetahui kompetensi kerja dan beban kerja berpengaruh terhadap produktivitas kerja surveyor pada kegiatan Container Survey di Depo Bimaruna Jaya.

\section{B. Metode Penelitian}

Metode yang digunakan dengan cara pengamatan langsung ke lapangan, melakukan penyebaran kuesioner kepada petugas surveyor in dan out, estimator, dan supervisor maintenance and repair Depo Bimaruna Jaya dan melakukan wawancara kepada manajer depo dan supervisor maintenance and repair. Jenis penelitian yang digunakan yaitu deskriptif kualitatif. Pada penyebaran kuesioner dan wawancara dilakukan teknik purposive sampling dengan jumlah sampel 8 orang.

\section{Hasil dan Pembahasan}

PT. Bimaruna Jaya merupakan anak perusahaan dari Korindo Grup yang bergerak dalam bidang jasa penanganan dan penumpukkan peti kemas. PT. Bimaruna Jaya terletak di JL. Raya Cakung Cilincing Km 1,5 Jakarta Timur. Berikut ini merupakan gambaran lokasi PT. Bimaruna Jaya. 


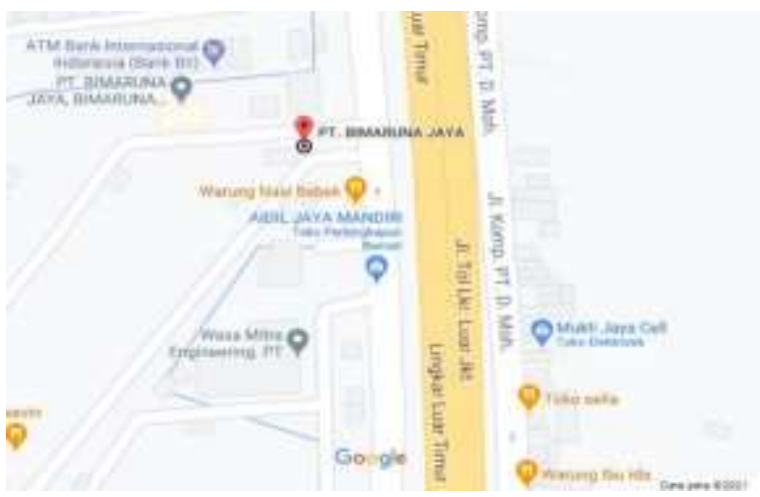

Gambar 1. Wilayah Usaha PT. Bimaruna Jaya

Sumber : Google Maps (2021)

1. Karakteristik Responden

Sampel penelitian ini terdapat sejumlah 8 orang yang terdiri dari karyawan PT. Bimaruna Jaya Divisi Depo Bagian surveyor in dan out, estimator, dan supervisor maintenance and repair. Umur, jenis kelamin, lama bekerja, pendidikan terakhir dan jabatan dalam bekerja merupakan karakteristik yang ingin diketahui. Data diri responden dapat diperjelas dalam jumlah dan persentase dibawah ini :

1.1 Karakteristik Responden Berdasarkan Jenis Kelamin

Berdasarkan hasil pengolahan data, diketahui bahwa sejumlah 8 orang responden berjenis kelamin laki-laki.
Untuk melihat rekapitulasi sebaran data berdasarkan jenis kelamin dapat di lihat dalam diagram berikut :

\section{Jenis Kelamin}

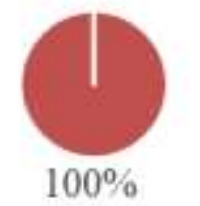

- Perempuan - Laki-laki = -

Sumber : Data Olahan Pribadi (2021)

Gambar 2. Karakteristik Responden

Berdasarkan Jenis Kelamin

1.2 Karakteristik Responden Berdasarkan Berdasarkan hasil pengolahan data, untuk karakteristik umur responden didapati bahwa terdapat usia 21-30 tahun sejumlah 1 orang, usia 31-40 tahun sejumlah 3 orang, usia 41-50 tahun sejumlah 2 orang dan usia diatas 50 tahun sejumlah 2 orang. Untuk melihat rekapitulasi sebaran data berdasarkan umur dapat di lihat dalam diagram berikut :

\section{Umur}

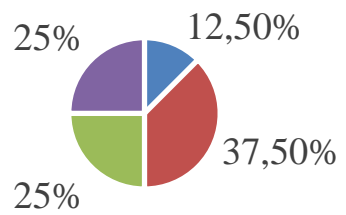

- 21-30 th $-31-40$ th $\approx 41-50$ th $->50$ th

Gambar 3. Karakteristik Responden Berdasarkan Umur

Sumber : Data Olahan Pribadi (2021) 
1.3 Karakteristik Responden Berdasarkan Pendidikan Terakhir

Berdasarkan hasil olahan data yang dilakukan, karakteristik tingkat pendidikan terakhir responden terdapat 1 orang yang pendidikan terakhirnya SD, 5 orang pendidikannya SMA/SMK, 1 orang yang pendidikannya D3 dan 1 orang pendidikan terakhirnya S1. Untuk melihat rekapitulasi sebaran data berdasarkan pendidikan terakhir dapat di lihat dalam diagram berikut :

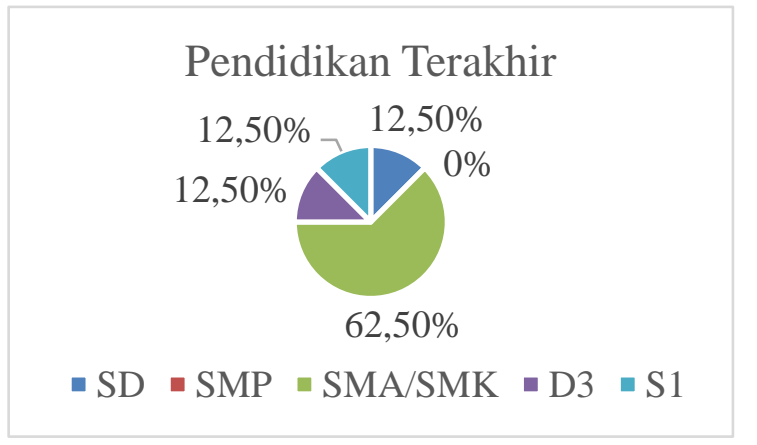

Gambar 4. Karakteristik Responden

\section{Berdasarkan Pendidikan Terakhir}

Sumber : Data Olahan Pribadi (2021

1.4 Karakteristik Responden Berdasarkan Lama Bekerja

Berdasarkan hasil olahan data yang dilakukan pada karakteristik lama bekerja responden terdapat sejumlah 3 orang bekerja kurang dari 5 tahun, 1 orang yang bekerja sudah $6-10$ tahun, 1 orang yang sudah bekerja 16-20 tahun dan sebanyak 3 orang yang bekerja sudah lebih dari 21 tahun Untuk melihat rekapitulasi sebaran data berdasarkan lama bekerja dapat di lihat dalam diagram berikut :

\section{Lama Bekerja}

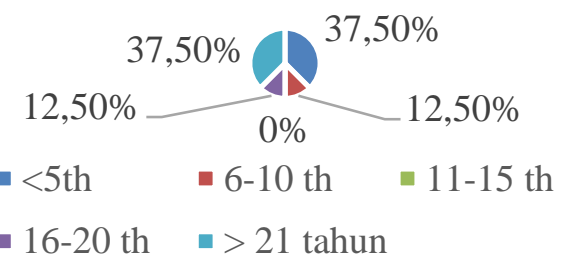

\section{Gambar 5. Karakteristik Responden}

\section{Berdasarkan Lama Bekerja}

Sumber : Data Olahan Pribadi (2021)

1.5 Karakteristik Responden Berdasarkan Jabatan

Berdasarkan hasil olahan data yang dilakukan pada karakteristik jabatan dapat dilihat sebanyak 3 orang sebagai Surveyor In yang mengecek kondisi saat pertama kali container masuk ke area depo, 2 orang sebagai Surveyor Out yang mengecek kondisi container yang ingin keluar dari area depo, 2 orang sebagai Estimator yang menghitung biaya kerusakan pada container yang telah diperiksa oleh petugas surveyor dan 1 orang sebagai Supervisor Maintenance and Repair. 
Rekapitulasi sebaran data jabatan dapat di lihat dalam diagram berikut :

\section{Jabatan}

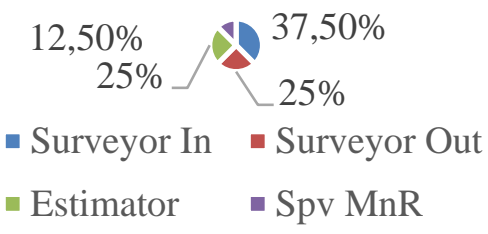

Gambar 6. Karakteristik Responden Berdasarkan Jabatan

Sumber : Data Olahan Pribadi (2021)

2. Apakah kompetensi kerja berpengaruh terhadap produktivitas kerja surveyor pada kegiatan Container Survey di Depo Bimaruna Jaya.

Tabel 1. Jawaban Responden Terhadap Kompetensi Kerja

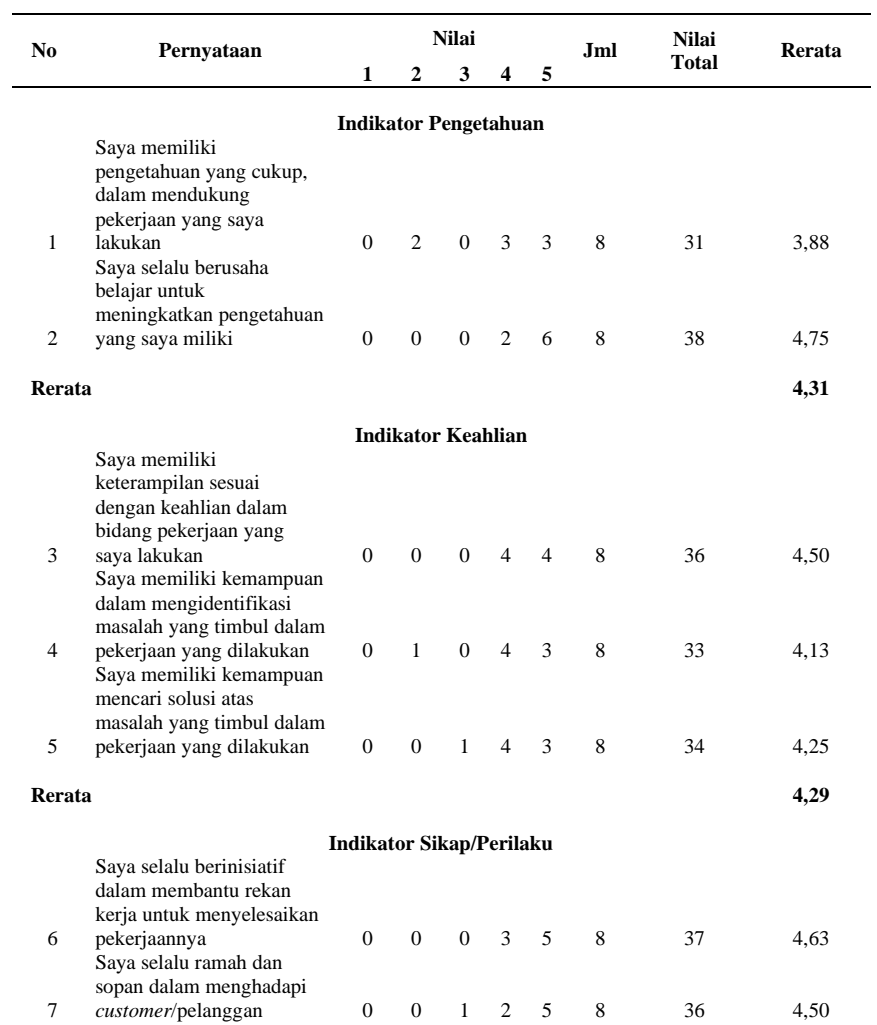

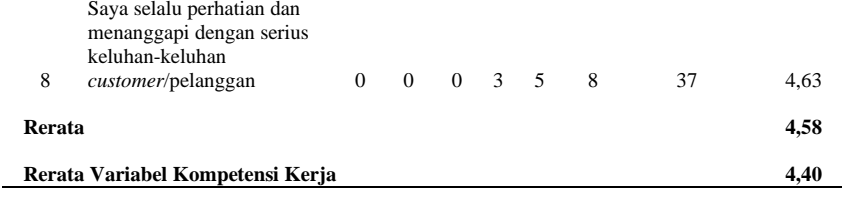

Sumber : Data Olahan (2021)

Berdasarkan tabel 1 diketahui bahwa rerata dari jawaban responden terhadap variabel kompetensi kerja berada pada nilai 4,40 yang bermakna sangat baik. Secara keseluruhan pada indikator sikap/perilaku petugas surveyor memiliki rerata jawaban responden paling tinggi dengan nilai 4,58 yang bermakna sangat baik. Hal ini menunjukkan bahwa petugas surveyor memiliki sikap/perilaku sangat baik dari segi inisiatif dalam membantu rekan kerja, ramah dan sopan dalam menghadapi customer dan selalu perhatian dan menanggapi dengan serius keluhan customer.

Berdasarkan wawancara yang dilakukan, dalam melakukan kegiatan container survey petugas surveyor diharuskan memiliki keahlian khusus seperti menguasai kode-kode yang terdapat pada CEDEX (Container Equipment Data Exchange) yang meliputi kode komponen, lokasi kerusakan, jenis kerusakan, jenis perbaikan, jenis pembersihan dan ketentuan-ketentuan kerusakan container. Hal ini dimaksudkan karena kompetensi kerja yang dimiliki seorang 
surveyor dapat mempengaruhi

produktivitas kerja karena semakin rendah pengetahuan petugas surveyor akan semakin banyak keluhan dan lost survey pada kegiatan container survey.

3. Apakah beban kerja berpengaruh terhadap produktivitas kerja surveyor pada kegiatan Container Survey di Depo Bimaruna Jaya.

Tabel 2. Jawaban Responden Terhadap Beban Kerja

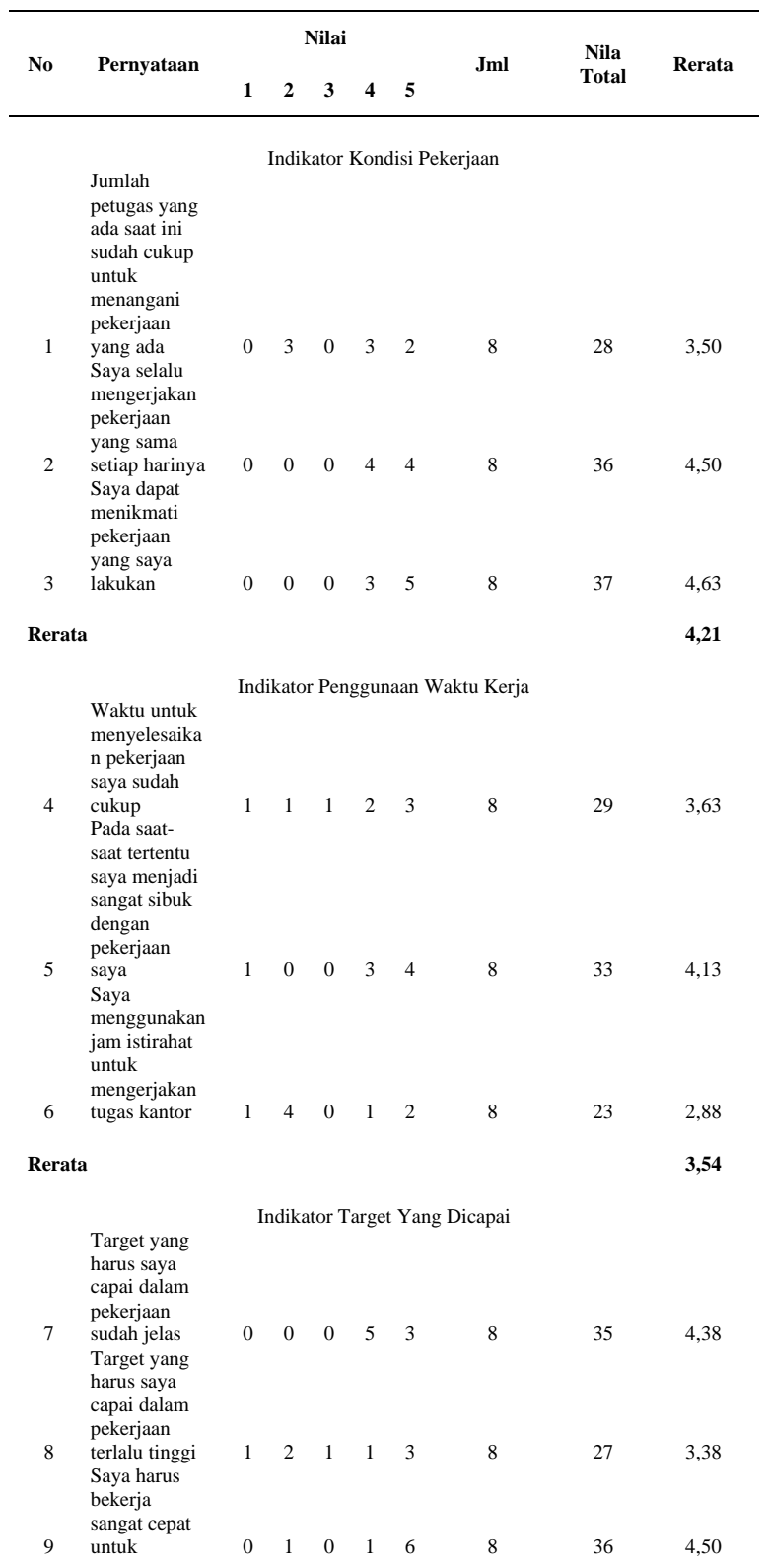

menyelesaika
n pekerjaan

saya

Rerata

4,08

Rata - Rata Variabel Beban Kerja 3,94

Sumber : Data Olahan (2021)

Berdasarkan gambar 2 diketahui bahwa rerata dari jawaban responden terhadap variabel beban kerja berada pada 3,94 yang bermakna baik. secara keseluruhan indikator pekerjaan petugas surveyor memiliki rerata dari jawaban responden paling tinggi yaitu senilai 4,21 yang bermakna sangat baik. Hal ini menunjukkan bahwa kondisi pekerjaan petugas surveyor memiliki kondisi pekerjaan yang baik dan nyaman sehingga para petugas surveyor dapat menikmati pekerjaan yang dilakukannya.

Berdasarkan observasi dan wawancara yang dilakukan dapat diketahui bahwa jumlah petugas surveyor in saat ini kurang mencukupi untuk menangani proses pengecekan container. Hal ini dikarenakan oleh jumlah pergerakan container yang masuk dan keluar area depo per harinya. Pada saat-saat tertentu pergerakan container yang masuk dan keluar mengalami peningkatan dan hal ini yang menyebabkan petugas yang bekerja 1 orang per shift merasa kelelahan. Hal ini dapat berdampak pada tingginya lost survey pada kegiatan survey container. 
Beban kerja yang diberikan perusahaan kepada surveyor dapat mempengaruhi produktivitas kerja. Terdapat beberapa faktor yang menyebabkan beban kerja yang diberikan kepada petugas surveyor yang mempengaruhi produktivitas kerja yaitu jam kerja yang berlebih dan kurangnya petugas surveyor untuk menangani pekerjaan men-survey container. Berdasarkan wawancara yang dilakukan dapat diketahui bahwa maksimal jam kerja seorang surveyor adalah 8 jam.

4. Apakah kompetensi dan beban kerja berpengaruh terhadap produktivitas kerja surveyor pada kegiatan Container Survey di Depo Bimaruna Jaya.

Tabel 3. Jawaban Responden Terhadap Produktivitas Kerja

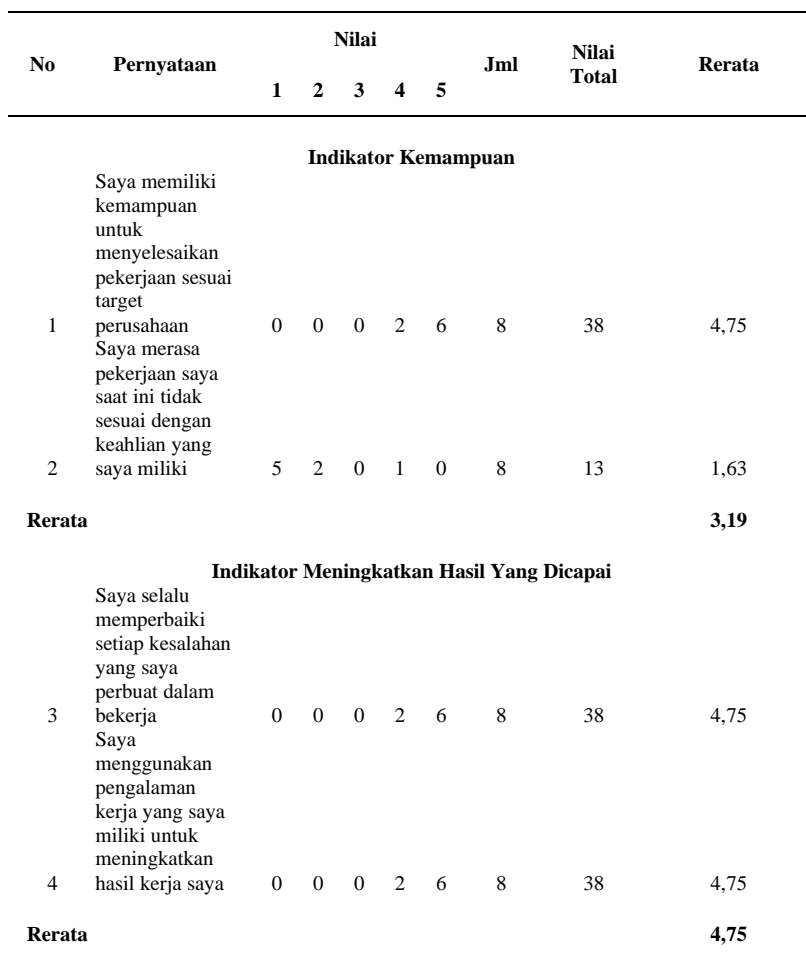
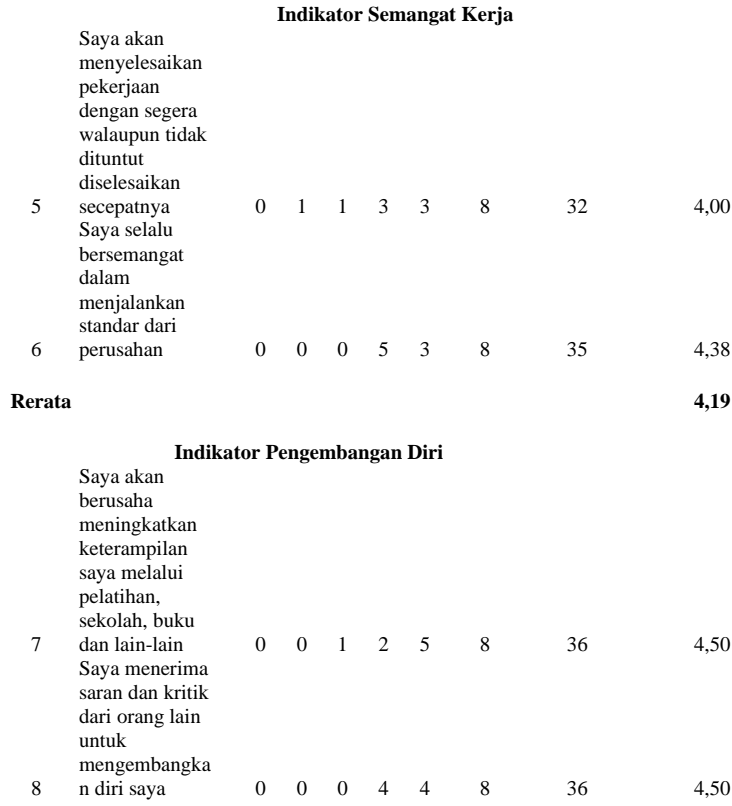

Rera

Indikator Mutu

Mutu pekerjaan

yang dihasilkan

oleh saya sesuai

dengan standar

yang telah

ditetapkan

Saya berusaha

untuk

meningkatkan

kualitas kerja

Rerata

4,50

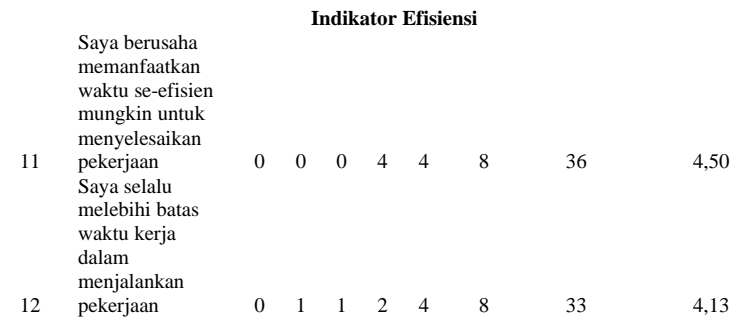

Rerata

Rerata Variabel Produktivitas Kerja

Sumber : Data Olahan (2021)

Berdasarkan tabel 3 diketahui bahwa rerata dari jawaban responden terhadap variabel produktivitas kerja berada pada nilai 4,26 yang bermakna sangat baik. Secara keseluruhan indikator meningkatkan hasil yang dicapai petugas surveyor memiliki rerata jawaban responden yang paling tinggi senilai 4,75 yang bermakna 
sangat baik. Hal ini menyatakan bahwa petugas surveyor memiliki kepedulian yang tinggi untuk meningkatkan hasil yang dicapai dengan sangat baik dari segi sikap untuk memperbaiki kesalahan yang diperbuat serta penggunaan pengalaman kerja guna peningkatan hasil.

Berdasarkan wawancara yang dilakukan terdapat kendala atau permasalahan terhadap hasil kerja petugas surveyor seperti terjadinya lost survey. Hal ini menunjukkan perlunya peningkatan hasil kerja dari surveyor guna meningkatkan produktivitas kerjanya. Dalam meningkatkan produktivitas kerja seorang surveyor diperlukan kegiatan seperti training, penambahan petugas surveyor yang berkompeten dan penambahan alat-alat penunjang untuk kegiatan survey container.

Produktivitas kerja seorang petugas surveyor dapat dipengaruhi oleh kompetensi dan beban kerja dengan target yang telah ditetapkan perusahaan. Contohnya kalau petugas surveyor tidak memiliki kompetensi yang baik dan beban kerja yang lebih atau kurang, maka surveyor tersebut merasa bekerja tidak ada tuntutan, tidak ada tanggung jawab, tidak ada beban yang harus dikerjakan jadi target tidak tercapai. Tetapi jika kompetensi dan beban kerja ditekankan kepada petugas surveyor, maka mereka akan memacu produktivitasnya untuk memenuhi target yang sudah ditetapkan perusahaan.

\section{Simpulan}

Berdasarkan observasi lapangan dengan menggunakan kuesioner dan wawancara, dapat disimpulkan sebagai berikut :

1. Dapat diketahui bahwa rerata jawaban responden sebanyak 8 orang terhadap variabel kompetensi kerja berada pada nilai 4,40 yang bermakna sangat baik. Hal ini menunjukkan bahwa petugas surveyor Depo Bimaruna Jaya memiliki kompetensi yang sangat baik. Pada hasil penyebaran kuesioner dan wawancara menyatakan bahwa kompetensi kerja yang dimiliki seorang surveyor dapat mempengaruhi produktivitas kerja karena semakin rendah pengetahuan petugas surveyor akan semakin banyak keluhan dan lost survey pada kegiatan survey container.

2. Dapat diketahui bahwa rerata jawaban responden sebanyak 8 orang terhadap variabel beban kerja berada pada nilai 3,94 yang bermakna baik. Hal ini menyatakan bahwa petugas surveyor Depo Bimaruna Jaya memiliki beban 
kerja yang baik. Dari hasil penyebaran kuesioner dan wawancara menyatakan bahwa beban kerja yang diberikan perusahaan kepada surveyor dapat mempengaruhi produktivitas kerja. Terdapat beberapa faktor yang menyebabkan beban kerja yang diberikan kepada petugas surveyor yang mempengaruhi produktivitas kerja yaitu jam kerja yang berlebih sebanyak 12 jam dan kurangnya petugas surveyor untuk menangani pekerjaan men-survey container.

3. Diketahui bahwa rerata jawaban responden sebanyak 8 orang terhadap variabel produktivitas kerja berada pada nilai 4,26 yang bermakna sangat baik. Hal ini menyatakan bahwa petugas surveyor Depo Bimaruna Jaya memiliki produktivitas kerja yang baik, yang tentutnya akan membuat segala bentuk pekerjaan berjalan sebagaimana mestinya. Dari hasil penyebaran kuesioner dan wawancara menyatakan bahwa Produktivitas kerja seorang petugas surveyor dapat dipengaruhi oleh kompetensi dan beban kerja dengan target yang telah ditetapkan perusahaan. Contohnya kalau petugas surveyor tidak memiliki kompetensi yang baik dan beban kerja yang lebih atau kurang, maka surveyor tersebut merasa bekerja tidak ada tuntutan, tidak ada tanggung jawab, tidak ada beban yang harus dikerjakan jadi target tidak tercapai. Tetapi jika kompetensi dan beban kerja ditekankan kepada petugas surveyor, maka mereka akan memacu produktivitasnya untuk memenuhi target yang sudah ditetapkan perusahaan.

\section{E. Daftar Pustaka}

Hadi, W., Wibowo, \& Rachbini, W. (2021). Foremans Job Satisfaction With the Company Loading and Unloading Containers in Dki Jakarta. International Journal of Advanced Research, 9(08), 900-911. https://doi.org/10.21474/ijar01/13343

JUMANTORO, R., FARIDA, U., \& SANTOSO, A. (2019). Pengaruh Kompetensi, Motivasi Kerja, Beban Kerja, Dan Pelatihan Terhadap Produktivitas Kerja Sumber Daya Manusia Koperasi Serba Usaha Anak Mandiri Ponorogo. ISOQUANT: Jurnal Ekonomi, Manajemen Dan Akuntansi, $\quad 3(1), \quad 106$. https://doi.org/10.24269/iso.v3i1.244

Kennedy, P. S. J., Tobing, S. J. L., Hidayat, T. R., \& ... (2018). Manajemen Operasional Maintenance dan Repair Depo Peti Kemas Kosong: Studi Kasus pada PT Gns Jakarta. Ikra-Ith $\quad$..., 1(2), 53-66. 
http://journals.upi-

yai.ac.id/index.php/IKRAITH-

EKONOMIKA/article/download/383/ 263

Kurniawan, H., W, M. M., \& Fathoni, A. (2016). Pengaruh Reward, Punishment, Beban Kerja, Dan Pelatihan Terhadap Produktivitas Kerja Karyawan (Studi Kasus Pada Karyawan Pt Andalan Arthalestari Semarang). Journal of Management, 2(2), 10.

Peraturan Menteri Perhubungan Nomor PM 83 Tahun 2016. (2016). Peraturan Menteri Perhubungan Republik Indonesia Nomor PM 83 Tahun 2016

Tentang Penyelenggaraan Dan Pengusahaan Depo Peti Kemas. Menteri Perhubungan.

Rahmayanti, H., \& Tirtayadi, A. (2011).

Faktor Yang Mempengaruhi Produktivitas Bongkar Muat Container Kapal Keagenan Pt. Mitra Samudra Jaya Lines Di Jakarta .... Logistik, $\quad I V(1), \quad 22-32$. http://journal.unj.ac.id/unj/index.php/l ogistik/article/view/13658

Undang-Undang Republik Indonesia No.

13 Tahun 2003. (2003). UndangUndang Republik Indonesia No.13 Tahun 2003 tentang Ketenagakerjaan.

Undang-Undang, $\quad 1, \quad 1-34$. http://www.kemenperin.go.id/kompet ensi/UU_13_2003.pdf 